\title{
The right coronary artery originating from the distal circumflex artery
}

\author{
Songul Cuglan', Bilal Cuglan² \\ ${ }^{1}$ Department of Anatomy, Faculty of Medicine, Beykent \\ University, Istanbul, Turkey \\ ${ }^{2}$ Department of Cardiology, Faculty of Medicine, \\ Bahçeşehir University, Istanbul, Turkey
}

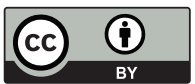

This work is licensed under Creative Commons Attribution 4.0 International License

Received: 2020-01-02

Accepted: 2020-01-10

UDC: 616.1

\section{J Clin Med Kaz 2019; 4(54):47-50}

Corresponding Author: Dr. Songul Cuglan, PhD, Department of Anatomy, Faculty of Medicine, Beykent University, Buyukcekmece Campus, Beykent, 34550, Istanbul, Turkey. Tel.: +90.212.4441997

E-mail: s-cuglan2921@hotmail.com
Abstract

We report a case of anomalous origin of the right coronary artery in a 58 -year-old male patient. The patient had a single coronary ostium originating from the left sinus valsalva. Right coronary artery was originating from the distal circumflex artery. There was no other cardiac anomaly in association with this rare case. Our patient had only severe atherosclerosis in the proximal left anterior descending artery with normal coronary flow in the circumflex artery. Generally, cases with single coronary ostium are considered to be benign. However, these patients experience the symptoms of coronary artery disease more critically because of dependence on one coronary artery.

Key words: coronary angiography, cardiovascular abnormalities, coronary vessel anomalies

\section{ДИСТАЛЬДЫ АЙНАЛДЫРА ҚОРШАЙТЫН АРТЕРИЯДАН БАСТАЛАТЫН ОН ЖАҚ КОРОНАРЛЫҚ АРТЕРИЯ}

\section{С. Чуглан ${ }^{1}$, Б. Чуглан}

${ }^{1}$ Анатомия кафедрасы, Медицина факультеті, Бейкент Университеті, Ыстамбұл, Түркия

${ }^{2}$ Кардиология кафедрасы, Медицина факультеті, Бахчешехир Университеті, Ыстамбұл, Түркия

\section{ТҰЖЫРЫМДАМА}

Бұл жұмыста біз 58 жастағы ер адамда оң жақ коронарлық артерияның аномалды ағып кету жағдайын қарастырамыз. Науқаста Вальсальваның сол жақ синусынан ағатын жалғыз коронарлық саға болды. Оң жақ коронарлық артерия дистальды айналдыра қоршайтын артериядан ағатын. Бұл сирек кездесетін жағдаймен байланысты басқа ешқандай жүрек ақауы болған жоқ. Біздің пациентте сол жақ коронарлық артерияның проксимальды алдыңғы төмен түсетін бөлігінде ауыр атеросклероз ғана болды, айналдыра қоршайтын артерияда қалыпты коронарлық қан ағымы болды. Әдетте, бір коронарлық сағасы бар ісіктер қатерсіз болып саналады. Алайда, мұндай пациенттер бір коронарлық артерияға тәуелді болғандықтан, жүректің ишемиялық ауруының белгілерін қатты сезінеді.

Негізгі сөздер: коронарлық ангиография, жүрек-қан тамырлары бұзылыстары, коронарлық артериялық аномалиялар

\section{ПРАВАЯ КОРОНАРНАЯ АРТЕРИЯ, ОТХОДЯЩАЯ ОТ ДИСТАЛЬНОЙ ОГИБАЮЩЕЙ АРТЕРИИ}

\section{С. Чуглан ${ }^{1}$ Б. Чуглан ${ }^{2}$}

'Кафедра анатомии, Факультет медицины, Университет Бейкент, Стамбул, Турция

${ }^{2}$ Кафедра кардиологии, Факультет медицины, Университет Бахчешехир, Стамбул, Турция

\section{PEЗЮME}

В данной работе рассматривается случай аномального отхождения правой коронарной артерии у 58-летнего мужчины. У пациента было единственное коронарное устье, отходящее от левого синуса Вальсальвы. Правая коронарная артерия отходила от дистальной огибающей артерии. Никакого другого порока сердца, связанного с данным редким случаем не было. У нашего пациента был только тяжелый атеросклероз в проксимальной передней нисходящей ветви левой венечной артерии с нормальным коронарным кровотоком в огибающей артерии. Как правило, случаи с одним коронарным устьем считаются доброкачественными. Тем не менее, такие пациенты испытывают симптомы коронарной болезни сердца более серьезно в связи с зависимостью от одной коронарной артерии.

ключевые слова: коронарная ангиография, сердечно-сосудистые нарушения, аномалии коронарных сосудов

\section{Introduction}

A single coronary artery (SCA) occurring in isolation, without being associated with other structural heart disease is very rarely reported in medical literature. Its occurrance in less than 0.02 to $0.06 \%$ of the general population [1]. Classifications have been determined by different anatomical variations depend on either angiographically or necropsy findings [2]. We hereby present a case of a patient with one vessel disease and all coronary arteries originating from a single ostium in the left sinus of Valsalva with an anomalous course of the right coronary artery (RCA) originating as a branch of the distal circumflex artery (CX). 


\section{Case report}

A 58-year-old man complaining of atypical chest discomfort with no family history of coronary artery disease (CAD) was admitted to İstinye University Liv Hospital. The associated risk factors included smoking and hypercholesterolemia. Cardiac auscultation and peripheral pulses were normal. The baseline electrocardiogram was normal. An echocardiogram revealed normal atrioventricular morphology with no regional wall motion abnormality. Serial cardiac enzymes were normal. The treadmill test was positive for inducible myocardial ischemia. He underwent coronary angiography wereby RCA could not be selectively cannulated. A non-selective injection revealed no coronary artery originating from the right sinus valsalva. The selective injection of the left coronary sinus revealed only left main coronary artery (LMCA) (Figure 1). After a short course, LMCA was divided into two branches: left anterior descending artery (LAD) and CX. CX was the dominant vessel. CX was located in the normal anatomical region and there was no lesion in the CX. In the distal part of CX, a lateral branch was observed along the RCA track (Figure 2). This side branch was normal along the posterior sulcus atriventricularis to the level of RCA. There was no other cardiac anomalies. A critical lesion was detected in proximal (osteal) LAD. Due to being not suitable for percutaneous coronary intervention (PCI), our patient was referred for surgery. During surgery, our patient was operated under cardiopulmonary bypass. His heart was arrested with intermittent antegrad cold blood cardioplegia. Distal anastomosis to LAD was performed by using left internal mammarian artery insitu. The aortic cross-clamping time was 57 minutes and extracorporeal circulation was 70 minutes. Early postoperative course was uneventiful. Our patient died in late postoperative course due to unknown reason of extracardiac manifestation.

\section{Discussion}

There are many factors in the embryological development of coronary vessels. These factors include chemotactic agents, adhesion molecules and multiple growth factors. Abnormalities of these signaling pathways may be responsible for coronary artery anomalies [3]. In our case, RCA ostium agenesis was present. There was a SCA originating from a single ostium in the left sinus of Valsalva.

The classification of SCA determined by Lipton et al. categorizes patterns according to the site of origin and anatomical distribution [1, 4-7]. Our patient was classified as L-I subtype of SCA in accordance with the modified Lipton et al. classification and an abnormal RCA originating from the distal left circumflex artery. A single coronary ostium with RCA originating from the distal left circumflex artery is a very rare anomaly. In literature review, there are few patients similar to our case [2,3,5,8-31] (Table 1). There were five cases reported in Turkey.

Table 1 Summary of characteristics of cases with right coronary artery (RCA) originating from distal circumflex artery

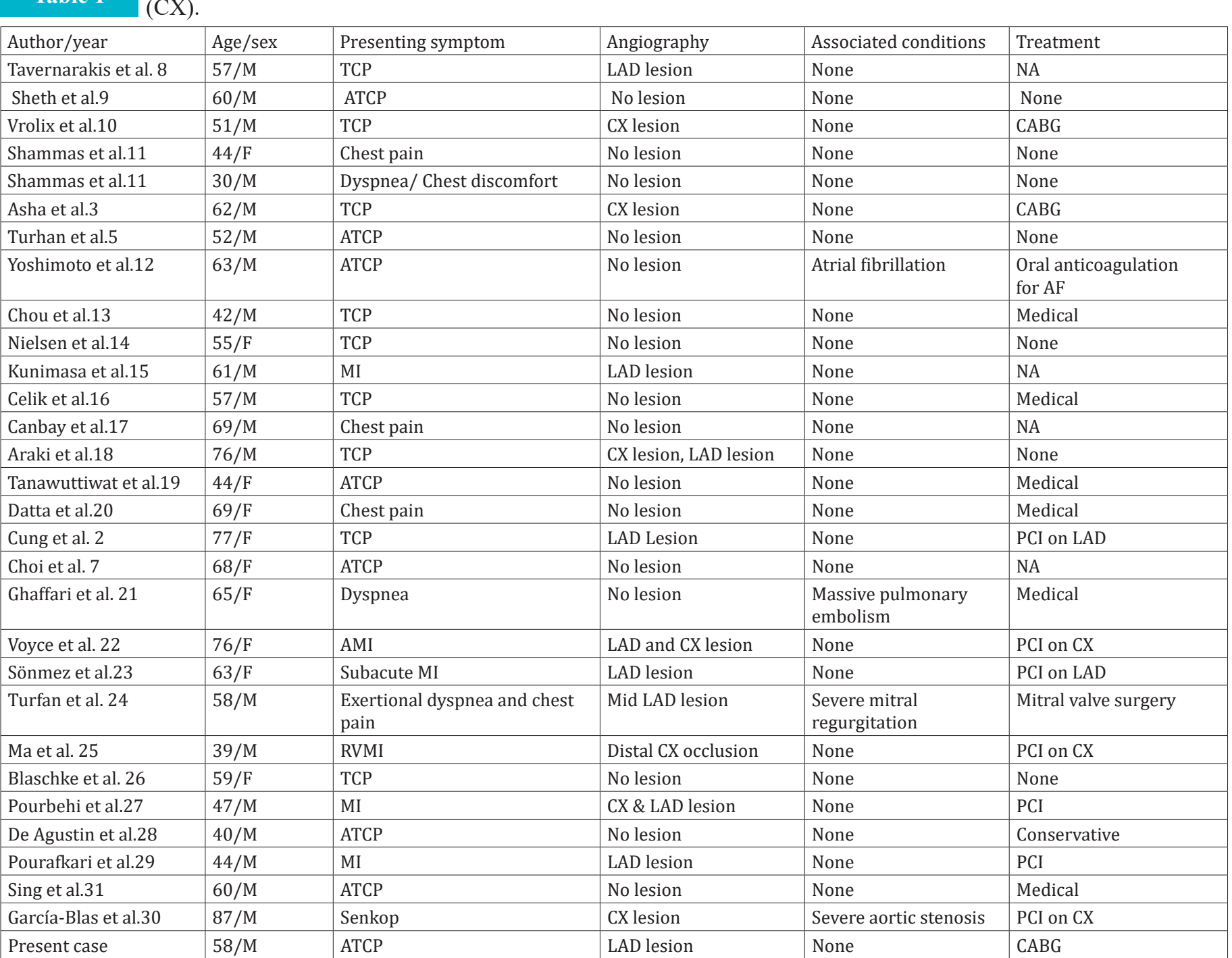

Male: M, Female:F, ATCP: Atipical chest pain, TCP: Tipical chest pain, MI: Myocardial infarction, AMI: Akut Myocardial infarction, RVMI:

Right Ventricular Myocardial Infarction, $\mathrm{PCI}=$ Percutaneous coronary intervention, $\mathrm{CABG}=\mathrm{Coronary}$ artery bypass grafting, NA: Not available. 


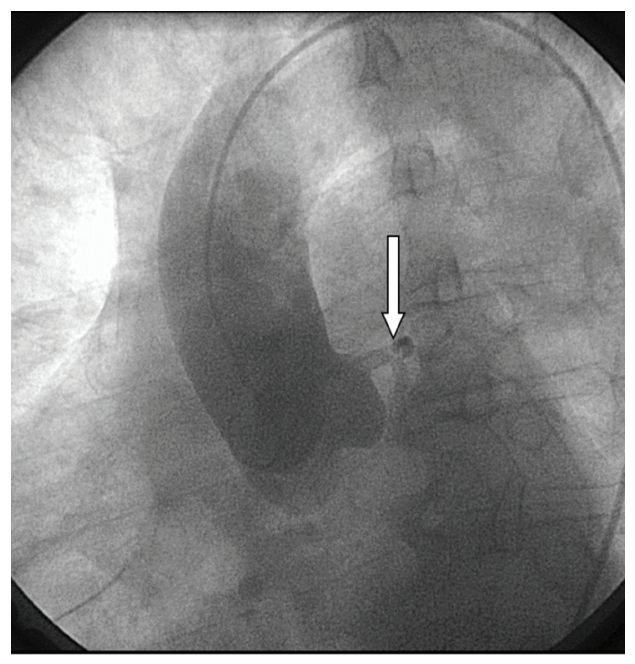

Figure 1 - Aortography revealing left main coronary artery (arrow) arising from left sinus of Valsalva and absence of right coronary ostium.

Anomalous of coronary arteries are associated with ischemia and sudden death, which could be the result of compression by the aorta and pulmonary artery. However, ischemia is also reported when an anomalous coronary artery does not run between the great vessels as in our case. Although SCA is generally considered benign, it has been associated with myocardial infarction and heart failure $[15,22]$. In our case, our patient did not have any history of myocardial infarction even though he had severe stenosis in LAD (osteal). Myocardial ischemia was detected with treadmill test. Myocardium ischemia was found in $20.6 \%$ of the cases $[15,22,23,25,27,29]$. Lesions were detected in both LAD and CX in three cases. Also, lesions were detected in LAD in six cases and $\mathrm{CX}$ in four cases. The location of the atherosclerotic lesion in this anomaly does not intervene clinically unless it corrupts the coronary flow. Percutaneous coronary intervention was performed in some cases with lesions. Only two patients with CX lesions underwent coronary artery bypass grafting $(\mathrm{CABG})[3,10]$. Due to being unsuitable for PCI, our patient was referred for CABG surgery.

The associated factors have been reported to be atrial fibrillation (AF), mitral valve insufficiency and massive pulmonary embolism in different cases. Ghaffari et al. reported massive pulmonary embolism in a SCA patient. They stated

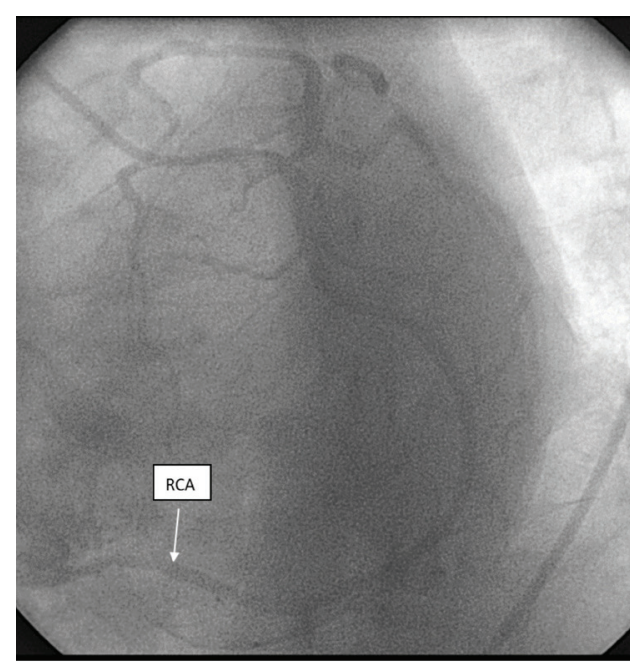

Figure 1 - Coronary angiogram from right caudal anterior oblique view showing the dominant circumflex artery(CX) with right coronary artery (RCA) (arrow) originating from the distal segment of CX.

that this is the patient's hemodynamic instability. This coronary anomaly is considered as a factor contributing to right ventricular (RV) dysfunction and prolonged unstable state of the patient [21]. In another case, a SCA was detected in one patient with severe mitral valve insufficiency [24]. Yoshimoto et al. reported SCA in a patient with chronic $\mathrm{AF}$ [12].

As the L-I variant of SCA is extremely rare, it is difficult to predict whether patients of this type of coronary artery anomaly are at high risk or benign course. Even L-I type of SCA were reported benign in most cases, in our case the patient died on the first postoperative day of his postoperative course because of hemodynamic instability. This could be due to extracardiac manifestation such as pulmonary emboli, RV dysfunction as mentioned above.

Generally, cases with single coronary ostium are considered to be benign. However, these patients experience the symptoms of CAD more critically because of dependence on one coronary artery. Therefore, we think that the recognition of this coronary artery anomaly will contribute to interventional cardiologists and cardiac surgeons.

Disclosures: There is no conflict of interest for all authors. Patient informed consent: obtained.

\section{References}

1. Agden JA, Goodyear AN. Patterns of distribution of the single coronary artery. Yale J Biol Med. 1970; 43: 11-21.

2. Chung SK, Lee SJ, Park SH, Lee SW, Shin WY, Jin DK. An extremely rare variety of anomalous coronary artery: right coronary artery originating from the distal left circumflex artery. Korean Circ J. 2010; 40(9): 465-467. https://doi.org/10.4070/kcj.2010.40.9.465

3. Asha M, Sriram R, Mukundan S, Abraham KA. Single coronary artery from the left sinus with atherosclerosis. Asian Cardiovascular and Thoracic Annals. 2003; 11(2):163-164. https://doi.org/10.1177/021849230301100217

4. Longnecker CG, Reemisa K, Creech JrD. Surgical implications of single coronary artery. Am Heart J. 1961; 61:382-386. https://doi. org/10.1016/0002-8703(61)90610-X

5. Turhan H, Duru E, Yetkin E, Atak R, Senen K. Right coronary artery originating from distal left circumflex: an extremely rare variety of single coronary artery. Int J Cardiol. 2003; 88:309-311. https://doi.org/10.1016/S0167-5273(02)00324-8

6. Lipton MJ, Barry WH, Obrez I, Silverman JF, Wexler L. Isolated single coronary artery: diagnosis, angiographic classification, and clinical significance. Radiology. 1979; 130:39-47. https://doi.org/10.1148/130.1.39

7. Choi HY, Kim JW, Moon JM, Kim YJ, Choi CU, Lim HE, et al. Unusual dominant course of left circumflex coronary artery to right coronary artery territory with absent right coronary artery. J Cardiol. 2010; 55(1):117-119. https://doi.org/10.1016/j.jjcc.2009.03.014

8. Tavernarakis A, Voudris V, Ifantis G, Tsaganos N. Anomalous origin of the right coronary artery arising from the circumflex artery. 
Clinical cardiology. 1986; 9(5):230-232. https://doi.org/10.1002/clc.4960090514

9. Sheth M, Dovnarsky M, Cha SD, Kini P, Maranhao V. Single coronary artery: right coronary artery originating from distal left circumflex. Cathet Cardiovasc Diagn. 1988; 14:180. https://doi.org/10.1002/ccd.1810140310

10. Vrolix MC, Geboers M, Sionis D, De Geest H, Van de Werf F. Right coronary artery originating from distal circumflex: an unusual feature of single coronary artery. Eur Heart J. 1991; 12:746. https://doi.org/10.1093/eurheartj/12.6.746

11. Shammas RL, Miller MJ, Babb JD. Single left coronary artery with origin of the right coronary artery from distal circumflex. Clinical cardiology. 2001; 24(1):90-92. https://doi.org/10.1002/clc.4960240115

12. Yoshimoto S, Hirooka K, Irino H, Abe H, Yasuoka Y, Yamamoto H et al. Anomalous Right Coronary Artery Originating From the Distal Left Circumflex Artery. Japanese heart journal. 2004; 45(4):679-683. https://doi.org/10.1536/jhj.45.679

13. Chou LP, Kao C, Lee MC, Lin SL. Right coronary artery originating from distal left circumflex artery in a patient with an unusual type of isolated single coronary artery. Japanese heart journal. 2004; 45(2):337-342. https://doi.org/10.1536/jhj.45.337

14. Nielsen BD, Frøbert O. Single coronary artery, ventricular tachycardia, and a family history of sudden death. Cardiology in review. 2005; 13(5):263-265. https://doi.org/10.1097/01.crd.0000148165.68016.1d

15. Kunimasa T, Sato Y, Ito S, Takagi T, Lee T, Saeki F, et al. Absence of the right coronary artery detected by 64-detector-row multislice computed tomography. International journal of cardiology. 2007; 115(2):249-250. https://doi.org/10.1016/j.ijcard.2006.01.039

16. Çelik T, İyisoy A, Yüksel Ç, Isik E. Anomalous right coronary artery arising from the distal left circumflex coronary artery. Anadolu Kardiyoloji Dergisi. 2008; 8(6): 459.

17. Canbay A, Ozcan O, Aydoğdu S, Diker E. Single coronary artery anomaly: a report of three cases. Turk Kardiyol Dern Ars. 2008; 36:473-475.

18. Araki M, Miyamoto M. Acute myocardial infarction of the right coronary artery originating from the distal left circumflex artery. Circulation Journal. 2008; 0810080107-0810080107. https://doi.org/10.1253/circj.CJ-07-0747

19. Tanawuttiwat T, Harindhanavudhi T, Trivedi D. Anomalous Single Coronary Artery with Absent Right Coronary Artery Diagnosed with the Aid of 64-Slice Multidetector Computed Tomographic Angiography. Tex Heart Inst J. 2009; 36:362-363.

20. Datta S, Moussa T, Hussain F. Anomalous right coronary artery originating from the distal left circumflex artery: a novel coronary artery anomaly viewed by computed tomography and invasive angiography. The Canadian journal of cardiology. 2010; 26(6):e213. https:// doi.org/10.1016/S0828-282X(10)70404-9

21. Ghaffari S, Pourafkari L. Pulmonary embolism in a patient with a rare coronary anomaly - a clue to the importance of proximal right coronary artery branches. Kardiol Pol. 2010; 68(7):844-846.

22. Voyce SJ, Abughnia H. An unusual cause of right ventricular myocardial infarction. The Journal of invasive cardiology. 2010; 22(11):E172-175.

23. Sönmez O, Gül EE, Altunbaş G, Ozdemir K. Right coronary artery arising from the distal left circumflex artery. Turk Kardiyoloji Dernegi arşivi. 2011; 39(4):325-327. https://doi.org/10.5543/tkda.2011.00769

24. Turfan M, Aydın C, Elbey MA, Erdoğan E, Asoglu E, Basel H, et al. Right coronary artery originating from the distal left circumflex artery, evaluation using three imaging techniques. Clinics. 2012; 67(12):1517-1518. https://doi.org/10.6061/clinics/2012(12)28

25. Ma SH, Kim DH, Hur JY, Kim KS, Byun SJ, Park KH,et al. Right ventricular myocardial infarction due to right coronary artery total occlusion originating from the distal left circumflex artery. Korean circulation journal. 2012; 42(8):565-567. https://doi.org/10.4070/ kcj.2012.42.8.565

26. Blaschke F, Zimmermann E, Greupner J, Zohlnhoefer D, Krackhardt HW, Haverkamp W, et al. A Rare Case of a Congenital Single Coronary Artery: Right Coronary Artery Originating From the Distal Left Circumflex Artery. Vascular Disease Management. 2013; 10(11):E244-E247.

27. Pourbehi MR, Amini A, Farrokhi S. Single coronary artery with anomalous origin of the right coronary artery from the distal portion of left circumflex artery: a very rare case. The Journal of Tehran University Heart Center. 2013; 8(3):161-163.

28. de Agustin JA, de Diego JJG, Marcos-Alberca P, Rodrigo JL, Almeria C, Nuñez-Gil IJ et al. Single left coronary artery with the right coronary artery arising as a continuation from the distal circumflex coronary artery assessed by multislice computed tomography. International journal of cardiology. 2014; 174(3):814-815. https://doi.org/10.1016/j.ijcard.2014.04.145

29. Pourafkari L, Taban M, Ghaffari S. Anomalous origin of right coronary artery from distal left circumflex artery: a case study and a review of its clinical significance. Journal of cardiovascular and thoracic research. 2014; 6(2):127.

30. García-Blas S, Valero E, Escribano D, Bonanad C, Sanchis J, Núñez J. Guideliner use for the percutaneous treatment of right coronary artery arising from the left circumflex (L-type single coronary artery). International journal of cardiology. 2015;185: 2-3. https://doi. org/10.1016/j.ijcard.2015.03.084

31. Singh S, Sahoo SK, Tripathy MP, Jena G. Angiographic enigma: A single coronary artery with the right coronary artery originating from the distal left circumflex artery. Heart views: the official journal of the Gulf Heart Association. 2015; 16(3):104. https://doi. org/10.4103/1995-705X.164465

How to cite this article: Songul Cuglan, Bilal Cuglan. The right coronary artery originating from the distal circumflex artery. J Clin Med Kaz. 2019; 4(54):47-50 